\title{
PENINGKATAN KETERAMPILAN BERBICARA MELALUI PENDEKATAN PRAGMATIK MAHASISWA 2017 FAKULTAS MIPA UNIPA SURABAYA
}

\author{
Sri Budi Astuti ${ }^{1)}$, Wahju Bandjarjani' ${ }^{2)}$ \\ ${ }^{1,2}$ Fakultas Keguruan dan Ilmu Pendidikan, Universitas PGRI Adi Buana Surabaya \\ Email: ${ }^{1}$ sri.budi@unipasby.ac.id, ${ }^{2}$ wahjubanjaryani@gmail.com
}

\begin{abstract}
Abstrak
Penelitian ini bertujuan untuk mendeskripsikan bahwa pendekatan pragmatik dapat meningkatkan keterampilan berbicara mahasiswa Statistika 2017 FMIPA Unipa Surabaya. Penelitian ini merupakan penelitian tindakan kelas dengan proses daur ulang melalui dari tahap perencanaan, pelaksanaan tindakan, dan pemantauan, dan refleksi. Subjek penelitian adalah mahasiswa Statistika 2017 FMIPA Unipa Surabaya yang terdiri atas 25 mahasiswa. Lokasi penelitian berada di ruang kelas FMIPA Unipa Surabaya. Berdasarkan analisis aktivitas kelas ditunjukkan bahwa terdapat peningkatan aktivitas mahasiswa dalam pembelajaran keterampilan berbicara dengan pendekatan pragmatik dari siklus I yang rata-rata terlaksana 6 meningkat menjadi 8 pada siklus II. Dari analisis hasil belajar mahasiswa diketahui adanya peningkatan keterampilan berbicara dengan pendekatan pragmatik dari 71,04\% pada siklus I menjadi 79,57\% pada siklus II. Dengan demikian dapat disimpulkan bahwa pendekatan pragmatik dapat meningkatkan keterampilan berbicara mahasiswa Statistika 2017 Unipa Surabaya.
\end{abstract}

Kata kunci: Keterampilan Berbicara, Pendekatan Pragmatik, Penelitian Tindakan Kelas

\begin{abstract}
This study aims to describe that the pragmatic approach can improve the speaking skills of Statistics 2017 FMIPA Unipa Surabaya students. This research is a classroom action research with the process of recycling through the stages of planning, implementing actions, and monitoring, and reflection. The research subjects were 2017 Statistics FMIPA Unipa Surabaya students consisting of 25 students. The research location is in the FMIPA Unipa Surabaya classroom. Based on the analysis of class activities it was shown that there was an increase in student activity in learning speaking skills with a pragmatic approach from cycle I, which on average implemented 6 increased to 8 in cycle II. From the analysis of student learning outcomes it is known that there is an increase in speaking skills with a pragmatic approach from $71.04 \%$ in the first cycle to $79.57 \%$ in the second cycle. Thus it can be concluded that a pragmatic approach can improve the speaking skills of Statistics 2017 Unipa Surabaya students.
\end{abstract}

Keywords: Speaking skills, pragmatic approach, Class Room Research

\section{PENDAHULUAN}

Keterampilan berbahasa merupakan salah satu keterampilan yang dimiliki manusia. Dengan keterampilan ini, manusia dapat berkomunikasi dengan sesamanya. Berbagai kegiatan pun berjalan dengan lancar dan sukses karena keterampilan berbahasa. Keterampilan berbahasa bisa diperoleh melalui jalur pendidikan.
Dalam konteks pendidikan terutama di perguruan tinggi, pengajaran bahasa dikenal adanya keterampilan berbahasa yang harusdicapai oleh mahasiswa yang meliputi empat aspek, yaitu: (1) keterampilan mendengarkan, (2) keterampilan berbicara, (3) keterampilan membaca, dan (4) keterampilan menulis. Keempat keterampilan tersebut pada dasarnya merupakan suatu kesatuan, merupakan catur-tunggal. 
Keterampilan hanya dapat diperoleh dan dikuasai dengan jalan praktik dan banyak pelatihan. Melatih keterampilan berbahasa berarti pula melatih keterampilan berpikir (Tarigan, 2008:1). Dari keempat keterampilan berbahasa, keterampilan berbahasa yang sangat penting peranannya dalam upaya melahirkan generasi masa depan yang cerdas, kritis, kreatif, dan berbudaya adalah keterampilan berbicara.

Kridalaksana(dalam Tarigan1997:144) menjelaskan bahwa berbicara adalah "berkata; bercakap; berbahasa, atau melahirkan pendapat (dengan perkataan, tulisan, dsb.) atau berunding". Sementara itu, (Mulgrave dalam Tarigan 2008:15) menjelaskan berbicara adalah kemampuan mengucapkan bunyi-bunyi bahasa atau katakata untuk mengekspresikan pikiran.

Akan tetapi, berdasarkan hasil observasi empirik di lapangan menunjukkan fenomena keterampilan berbicara mahasiswa berada pada tingkat yang rendah; diksi (pilihan kata)-nya payah, kalimatnya tidak efektif, struktur tuturannya rancu, alur tuturannya pun tidak runtut dan kohesif. Demikian juga keterampilan berbicara mahasiswa 2017 FMIPA Unipa Surabaya. Berdasarkan hasil observasi, hanya 25\% (7 mahasiswa) dari 25 mahasiswa yang dinilai sudah terampil berbicara dalam situasi formal di depan kelas. Hal ini tampak dari tugas berbicara yang diberikan pengajar kepada 25 mahasiswa di kelas tersebut, yaitu hanya 7 mahasiswa yang mencapai batas ketuntasan dengan nilai hasil belajar yang ditentukan perguruan tinggi-FMIPA sebesar 70, mahasiswa yang lainnya belum tuntas. Hal itu dibuktikan dengan masih adanya kesulitan dari mahasiswa. Dari data yang ada menunjukkan bahwa pada keterampilan berbicara tersebut hanya 8 mahasiswa saja yang mendapatkan nilai di atas 70 dan 18 mahasiswa yang belum tuntas dan mendapatkan nilai di bawah 70 .

Berdasarkan hasil observasi di atas, pengajar bahasa Indonesia cenderung menggunakan pendekatan yang konvensional dan kurang inovasi sehingga kegiatan pembelajaran keterampilan berbicara berlangsung monoton dan membosankan Para peserta tidak diajak untuk belajar berbahasa, tetapi cenderung diajak belajar tentang bahasa. Akibatnya, keterampilan berbicara hanya sekadar melekat pada diri mahasiswa sebagai sesuatu yang rasional dan kognitif belaka, belum manunggal secara emosional dan afektif.

Dalam konteks demikian, diperlukan pendekatan pembelajaran keterampilan berbicara yang inovatif dan kreatif, sehingga proses pembelajaran bisa berlangsung aktif, efektif, dan menyenangkan. Mahasiswa tidak hanya diajak untuk belajar tentang bahasa secara rasional dan kognitif, tetapi juga diajak untuk belajar dan berlatih dalam konteks dan situasi tutur yang sesungguhnya dalam suasana yang dialogis, interaktif, menarik, dan menyenangkan.

Salah satu pendekatan pembelajaran yang diduga mampu mewujudkan situasi pembelajaran yang kondusif; aktif, kreatif, efektif, dan menyenangkan adalah pendekatan pragmatik. Ciri utama pendekatan pragmatik dalam pembelajaran keterampilan berbicara adalah penggunaan konteks tuturan (Tarigan, 2009:21). Konteks terdiri dari unsur-unsur, seperti: situasi, pembicara, pendengar, waktu, tempat adegan, topik, peristiwa, bentuk amanat, kode, dan sarana.

Melalui penggunaan pendekatan pragmatik dalam pembelajaran keterampilan berbicara, para mahasiswa 2017 FMIPA Unipa Surabaya akan mampu menumbuhkembangkan potensi intelektual, sosial, dan emosional yang ada dalam dirinya, sehingga kelak mereka mampu berkomunikasi dan berinteraksi sosial secara matang, arif, dan dewasa.

\section{METODE PENELITIAN}

Penelitian ini menggunakan teori pendekatan deskriptif kuantitatif. Penggunaan angka dalaam deksriptif kuantitatif dimulai dari pengumpulan data, penafsiran pada data tersebut, hingga tampilan hasil observasi yang dilakukan. Sedangkan berdasarkan jenisnya penelitian ini merupakan Penelitian Tindakan Kelas 
(PTK). Penelitian tindakan kelas yang lebih umum disebut PTK, merupakan sebuah proses daur ulang mulai dari tahap perencanaan, pelaksanaan tindakan dan pemantauan, refleksi yang mungkin diikuti dengan perencanaan ulang (Aqib, 2001: 105).

PTK memiliki beberapa tahap yang untuk melihat standar ketuntasan minimum, yaitu mellaui perubahan dari refleksi I ke refleksi II, dalam PTK selalu menetapkan hasil perbaikan atau peningkatan hasil yang konkret. Perubahan hasil yang menunjuk pada peningkatan merupakan tujuan pokok PTK, karena itu dalam penilaian tindakan ini sangat diutamakan hal berikut: perencanaan, Pelaksanaan Tindakan, Observasi, Refleksi.

Subjek penelitian yaitu mahasiswa statistika FMIPA Unipa Surabaya, yang terdiri atas 25 mahasiswa, dengan rincian 7 mahasiswa laki-laki dan 18 mahasiswa perempuan. Lokasi Penelitian berada di FMIPA Unipa Surabaya.

Instrumen penelitian adalah alat atau fasilitas yang digunakan oleh peneliti dalam mengumpulkan data agar pekerjaannya lebih mudah dan hasilnya lebih baik dalam arti lebih cermat, lengkap dan sistematis sehingga lebih mudah diolahnya (Arikunto, 2006: 160).Berikut instrumen dalam penelitian tindakan kelas pendekatan pragmatik. Pertama,lembar observasi pembelajaran berbicara seperti:lembar observasi dosen, lembar aktivitas dosen, lembar aktivitas mahasiswa, dan lembar hasil belajar mahasiswa. Kedua, tes.

Dari uraian di atas, data penelitian dianalisis dengan menggunakan teknik tabulasi data secara kuantitatif berdasarkan hasil tindakan yang dilaksanakan pada setiap siklus. Hasil tindakan pada setiap siklus dibandingkan dengan hasil tes awal untuk mengetahui persentase peningkatan keterampilan mahasiswa Statistika 2017 FMIPA Unipa Surabaya dalam menceritakan pengalaman yang mengesankan.

Pada setiap siklus dideskripsikan jumlah skor yang diperoleh semua siswa, daya serap, dan rata-rata skor untuk aspek kelancaran berbicara, ketepatan pilihan kata (diksi), struktur kalimat, kelogisan (penalaran), dan kontak mata. Selain itu, juga dideskripsikan jumlah skor, jumlah nilai, rata-rata nilai, dan tingkat daya serap, dan ketuntasan belajar siswa pada setiap siklus. Data yang dihasilkan dalam observasi kemudian dianalisis dengan mendeskripsikan aktivitas pengajar dan mahasiswa dari siklus I dan II, demikian juga hasil belajar mahasiswa siklus I dan II yang akan diuraikan pada bab IV.

Melalui pengamatan pada setiap siklus, pengajar dan mahasiswa dapat mengetahui frekuensi kejadian yang muncul pada saat pembelajaran sesuai dengan jenis kegiatan dengan frekuensi aktivitas keseluruhan dikalikan 100\%. Data tersebut dapat diolah dengan menggunakan rumus:

$\mathrm{P}=\frac{\mathrm{f}}{\mathrm{N}}$

Keterangan:

$\mathrm{P}$ adalah persentase frekuensi kejadian yang muncul. F adalah banyaknya aktivitas dosen dan mahasiswa yang muncul. N adalahjumlah aktivitas seluruhnya.

Untuk penghitungan prestasi belajar berbicara dengan pendekatan pragmatik, mahasiswa Statistika 2017 FMIPA Unipa Surabaya dengan menggunakan rumus penilaian:

Mean $=\frac{\sum \mathrm{x}}{N}$

Keterangan:

Mean adalah jumlah rata-rata. $\quad \Sigma \quad \mathrm{x}$ adalah jumlah seluruh nilai dalam kelas. $\quad \mathrm{N}$ adalahjumlah mahasiswa (Nurgiantoro, 2004: 400.)

Berdasarkan hasil observasi awal, mahasiswa statistika 2017 FMIPA Unipa Surabaya minat dan hasil nilai pada keterampilan berbicara masih rendah atau di bawah standar ketuntasan minimun. Rendahnya keterampilan berbicara pada mahasiswa disebabkan oleh beberapa faktor yang memengaruhinya ketika proses pembelajaran. Oleh karena itu, melalui penelitian tindakan kelas dengan pendekatan 
pragmatik mahasiswa dapat meningkatkan minat dan nilai dalam keterampilan berbicara. Berikut hasil penelitian dan pembahasan dalam penelitian tindakan kelas mahasiswa statistika 2017 FMIPA Unipa Surabaya.

\section{HASIL DAN PEMBAHASAN}

\subsection{Hasil}

Perencanaan dalam penelitian tindakan kelas pada mahasiswastatistika 2017 FMIPA Unipa Surabaya mengikuti alur yang sudah ditentukan baik pada siklus I dan siklus II. Perencanaan yang dimaksud meliputi penetapan materi pembelajaran yaitu data penelitian dianalisis dengan menggunakan teknik tabulasi data secara kuantitatif berdasarkan hasil tindakan yang dilaksanakan pada setiap siklus. Hasil tindakan pada setiap siklus dibandingkan dengan hasil tes awal untuk mengetahui persentase peningkatan keterampilan mahasiswa dalam menceritakan pengalaman yang mengesankan.

Pertama, pada setiap siklus dideskripsikan jumlah skor yang diperoleh semua mahasiswa, daya serap, dan rata-rata skor untuk aspek kelancaran berbicara, ketepatan pilihan kata (diksi), struktur kalimat, kelogisan (penalaran), dan kontak mata. Selain itu, juga dideskripsikan jumlah skor, jumlah nilai, rata-rata nilai, dan tingkat daya serap, dan ketuntasan belajar mahasiswa pada setiap siklus. Kedua, tindakan, meliputi seluruh kegiatan pembelajaran melalui model. Ketiga, observasi, dilaksanakan bersamaan dengan kegiatan pembelajaran meliputi aktivitas, minat dan hasil belajar mahasiswa.

Keempat, refleksi, meliputi kegiatan analisis minat dan hasil belajar mahasiswa dan sekaligus menyusun rencana perbaikan pada siklus berikutnya. Kelima, pelaksanaan penelitian dilakukan dosen dan pelaksanaan observasi dan refleksi selama penelitian berlangsung, sehingga secara tidak langsung kegiatan penelitian bisa terkontrol sekaligus menjaga kevalidan hasil penelitian.

Melalui perencanaan di atas, dapat diterapkan dalam ujuk kerja pada siklus I dan siklus II. Model unjuk kerja yang dilakukan adalah model proses dalam putaran siklus I dan siklus II, lebih dahulu menentukan pokok permasalahan untuk mendapatkan cara-cara peningkatan keterampilan berbicara melalui pendekatan pragmatik mahasiswa Statistika 2017 FMIPA Unipa Surabaya dan alternatif pemecahannya. Penelitian ini dilakukan dua kali putaran, dan kedua siklus tersebut merupakan rangkaian kegiatan yang saling berkaitan. Hal ini artinya pelaksanaan siklus II merupakan kelanjutan dan perbaikan dari pelaksanaan siklus I seperti yang diungkapkan dalam bagan di bawah ini:

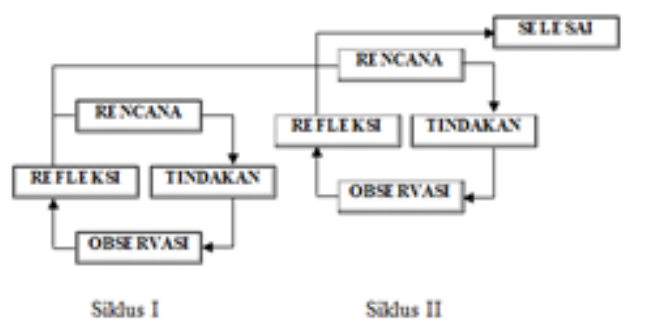

Gambar 1: Siklus Penelitian Tindakan

\subsection{Pembahasan}

Dalam pembahasan hasil penelitian ini, akan disajikan hasil deskriptif analisis persentase terhadap keberhasilan penerapan pendekatan pragmaticdalam meningkatkan keterampilan berbicara. Penilaian terhadap keberhasilan dapat dilihat dalam tabel analisis persentase di bawah ini: 1.Deskripsi Perubahan Hasil Refleksi

Refleksi didasarkan pada pengamatan sendiri oleh peneliti terhadap keberhasilan dan hasil perubahan refleksi setiap siklus dapat ditunjukkan sebagai berikut:

\section{a. Refleksi Siklus I}

1) Mahasiswa masih tidak mengerti terhadap metode belajar yang diterapkan dosen.

2) Perhatian dan partisipasi mahasiswa masih tergolong kurang

3) Penyajian materi oleh dosen sudah baik

4) Kemampuan dosen membimbing mahasiswa sudah baik

5) Proses penyelesaian tugas oleh mahasiswa tergolong kurang baik 
6) Pengelolaan waktu masih perlu ditingkatkan.

b.Refleksi Siklus II

1) Mahasiswa mulai mengerti terhadap metode belajar yang diterapkan dosen.

2) Perhatian dan partisipasi mahasiswa sudah baik.

3) Penyajian materi oleh dosen sangat baik.

4) Kemampuan dosen membimbing mahasiswa sangat baik.

5) Proses penyelesaian tugas oleh mahasiswa tergolong sangat baik

6) Pengelolaan waktu masih perlu ditingkatkan.

2. Deskripsi Perubahan Aktivitas Mahasiswa Berdasarkan hasil pengamatan maka selama siklus I dan siklus II diperoleh hasil pada perubahan aktivitas mahasiswa seperti yang ditunjukkan dalam tabel di bawah ini:

Tabel.1

Perubahan Aktivitas Mahasiswa Per Siklus

\begin{tabular}{|c|c|c|c|}
\hline $\begin{array}{l}\mathbf{N} \\
\mathbf{0}\end{array}$ & $\begin{array}{c}\text { Aktivitas } \\
\text { Mahasiswa }\end{array}$ & $\begin{array}{c}\text { Siklu } \\
\text { s } 1\end{array}$ & $\begin{array}{c}\text { Siklu } \\
\text { s } 2\end{array}$ \\
\hline 1 & $\begin{array}{l}\text { Memperhatikan } \\
\text { Penjelasan Dosen }\end{array}$ & 7 & 8 \\
\hline 2 & $\begin{array}{lr}\text { Bertanya } & \text { Kepada } \\
\text { dosen } & \text { tentang } \\
\text { Materi } & \text { Yang } \\
\text { Kurang Jelas }\end{array}$ & 5 & 8 \\
\hline 3 & $\begin{array}{l}\text { Melaksanakan } \\
\text { Tugas }\end{array}$ & 6 & 8 \\
\hline 4 & $\begin{array}{l}\text { Proses } \\
\text { Menganalisis, } \\
\text { Mengapresiasi dan } \\
\text { bertukar pendapat } \\
\text { dalam kelompok }\end{array}$ & 6 & 8 \\
\hline 5 & $\begin{array}{l}\text { Merefleksikan } \\
\text { Materi Pelajaran }\end{array}$ & 6 & 8 \\
\hline \multicolumn{2}{|c|}{ Jumlah } & 30 & 40 \\
\hline \multicolumn{2}{|c|}{ Rata-Rata } & 6 & 8 \\
\hline
\end{tabular}

Berdasarkan analisis tersebut dapat diketahui bahwa peningkatan kemampuan aktivitas mahasiswa dalam pembelajaran dalam meningkatkan keterampilan berbicara dengan pendekatan pragmatik terjadi peningkatan dari siklus I yang rata-rata aktivitasnya terlaksana hanya 6 menjadi 8 pada siklus II.

3. Deskripsi Perubahan Hasil Belajar

Mahasiswa

Berdasarkan hasil pengamatan maka selama siklus I dan siklus II diperoleh hasil pada perubahan aktivitas dosen seperti yang ditunjukkan dalam tabel di bawah ini:

Tabel. 2

Perubahan Hasil Belajar Per Siklus

\begin{tabular}{|c|c|c|c|c|c|}
\hline $\begin{array}{c}\text { N } \\
\text { o }\end{array}$ & $\begin{array}{c}\text { Res } \\
\text { pon } \\
\text { den }\end{array}$ & $\begin{array}{c}\text { Sikl } \\
\text { us } \\
\text { I }\end{array}$ & $\begin{array}{c}\text { Keter } \\
\text { anga } \\
\text { n }\end{array}$ & $\begin{array}{c}\text { Sikl } \\
\text { us } \\
\text { II }\end{array}$ & $\begin{array}{c}\text { Kete } \\
\text { rang } \\
\text { an }\end{array}$ \\
\hline 1 & & 72 & Baik & 90 & $\begin{array}{c}\text { Amat } \\
\text { Baik }\end{array}$ \\
\hline 2 & & 73 & Baik & 86 & $\begin{array}{c}\text { Amat } \\
\text { Baik }\end{array}$ \\
\hline 3 & & 72 & Baik & 87 & $\begin{array}{c}\text { Amat } \\
\text { Baik }\end{array}$ \\
\hline 4 & & 63 & $\begin{array}{c}\text { Cuku } \\
\text { p }\end{array}$ & 65 & $\begin{array}{c}\text { Cuku } \\
\text { p }\end{array}$ \\
\hline 5 & & 73 & Baik & 88 & $\begin{array}{c}\text { Amat } \\
\text { Baik }\end{array}$ \\
\hline 6 & & 64 & $\begin{array}{c}\text { Cuku } \\
\text { p }\end{array}$ & 79 & Baik \\
\hline 7 & & 74 & Baik & 79 & Baik \\
\hline 8 & & 73 & Baik & 82 & Baik \\
\hline 9 & & 62 & $\begin{array}{c}\text { Cuku } \\
\mathrm{p}\end{array}$ & 64 & $\begin{array}{c}\text { Cuku } \\
\text { p }\end{array}$ \\
\hline 10 & & 72 & Baik & 86 & $\begin{array}{c}\text { Amat } \\
\text { Baik }\end{array}$ \\
\hline 11 & & 72 & Baik & 81 & Baik \\
\hline 12 & & 72 & Baik & 83 & Baik \\
\hline 13 & & 73 & Baik & 77 & Baik \\
\hline 14 & & 61 & $\begin{array}{c}\text { Cuku } \\
\mathrm{p}\end{array}$ & 65 & $\begin{array}{c}\text { Cuku } \\
\text { p }\end{array}$ \\
\hline 15 & & 63 & $\begin{array}{c}\text { Cuku } \\
\text { p }\end{array}$ & 65 & $\begin{array}{c}\text { Cuku } \\
\text { p }\end{array}$ \\
\hline 16 & & 72 & Baik & 76 & Baik \\
\hline 17 & & 73 & Baik & 87 & $\begin{array}{c}\text { Amat } \\
\text { Baik }\end{array}$ \\
\hline 18 & & 73 & Baik & 90 & Amat \\
\hline
\end{tabular}




\begin{tabular}{|c|c|c|c|c|c|}
\hline & & & & & Baik \\
\hline 19 & & 80 & $\begin{array}{c}\text { Amat } \\
\text { Baik }\end{array}$ & 89 & $\begin{array}{c}\text { Amat } \\
\text { Baik }\end{array}$ \\
\hline 20 & & 61 & Baik & 75 & Baik \\
\hline 21 & & 71 & Baik & 79 & Baik \\
\hline 22 & & 75 & Baik & 87 & $\begin{array}{c}\text { Amat } \\
\text { Baik }\end{array}$ \\
\hline 23 & & 73 & Baik & 79 & Baik \\
\hline 24 & & 72 & Baik & 88 & $\begin{array}{c}\text { Amat } \\
\text { Baik }\end{array}$ \\
\hline 25 & & 62 & $\begin{array}{c}\text { puku } \\
\text { p }\end{array}$ & 65 & $\begin{array}{c}\text { Cuku } \\
\text { p }\end{array}$ \\
\hline $\begin{array}{c}\text { Ketuntas } \\
\text { an }\end{array}$ & 18 & & 20 & \\
\hline
\end{tabular}

Berdasarkan data di atas, tingkat keberhasilan mahasiswa dalam mengikuti pembelajaran kooperatif:

a. Siklus I

$$
M=\frac{\sum f}{n} \quad M=\frac{1776}{25}=71,04
$$

b. Siklus II

$$
M=\frac{\sum f}{n} \quad M=\frac{1992}{25}=79,68
$$

Berdasarkan perubahan hasil belajar tingkat keberhasilan mahasiswa dalam upaya meningkatkan keterampilan berbicara pada siklus I mencapai $71,04 \%$ dan mengalami kenaikan pada siklus II sebesar 79,57 \%. Hal ini dapat diasumsikan bahwa terdapat keberhasilan dengan pendekatan pragmatik dalam meningkatkan keterampilan berbicara pada mahasiswa. Gambaran secara utuh tentang perubahan aktivitas belajar mahasiswa dan ketuntasan belajar pada siklus I dan siklus II, peneliti akan menyajikan dalam bentuk diagram batang di bawah ini:
Grafik .1

Diagram Perubahan Ketuntasan Belajar Mahasiswa Setiap Siklus

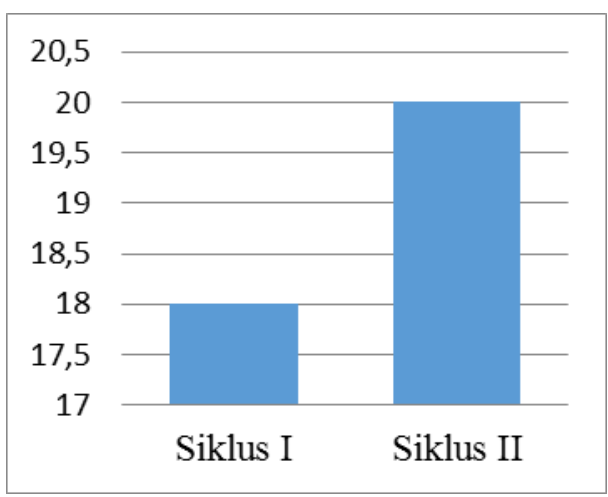

\section{KESIMPULAN DAN SARAN}

\subsection{Kesimpulan}

Berdasarkan analisis aktivitas kelas menunjukkan bahwa peningkatan kemampuan aktivitas mahasiswa dalam pembelajaran keterampilan berbicara dengan pendekatan pragmatik terjadi peningkatan dari siklus I yang rata-rata terlaksana 6 dan mengalami kenaikan pada siklus II sebesar 8 pada siklus II. Begitupun juga dnegan analisis hasil belajar, analisis hasil belajar mahasiswa terjadi perubahan upaya meningkatkan kemampuan keterampilan berbicara dengan menggunakan pendekatan pragmatik, pada siklus I mencapai $71,04 \%$ dan mengalami kenaikan pada siklus II sebesar $79,57 \%$. Hal ini dapat diasumsikan bahwa terdapat keberhasilan penggunaan pendekatan pragmatik dengan dalam usaha meningkatkan keterampilan berbicara pada mahasiswa statistika 2017 FMIPA Unipa Surabaya.

\subsection{Saran}

Berdasarkan hasil penelitian ini, ada beberapa hal yang dapat disarankan. Pertama, pengayaan terhadap model pembelajaran yang lebih variatif membuat mahasiswa merasa tidak bosan. Kedua, dalam penggunaan pendekatan pragmatik, dosen hendaknya dapat menggunakan metode 
Volume 71, Nomor 2, 1 Desember 2019

pembelajaran yang variatif untuk membimbing mahasiswa dalam meningkatkan kemampuan keterempilan berbicara.

\section{REFERENSI}

Aqib, Zainal. 2001. Penelitian Tindakan Kelas. Bandung : Yrama Widya.

Arikunto, Suharsimi. 2006. Prosedur Penelitian Suatu Pendekatan Praktik. Jakarta : Rineka Cipta. . 2008. Dasar - Dasar Evaluasi Pendidikan. Jakarta : Bumi Aksara.

Muslich, Masnur. 2010. Melaksanakan PTK itu mudah. Jakarta : PT Bumi Aksara.

Nurgiyantoro, Burhan, dkk. 2004. Statistik Terapan untuk Penelitian Ilmu-ilmu. Sosial. Yogyakarta. Gadjah Mada University Press.

Tarigan, Henry Guntur. 2008. Membaca Sebagai Suatu Keterampilan Berbahasa .Bandung : Angkasa.

Tarigan , Djago. 1997. Pengembangan Keterampilan Berbicara. Jakarta : Depdikbud.

---------, Henry Guntur. 2008. BerbicaraSebagai Suatu Keterampilan Berbahasa. Bandung : Angkasa.

Tarigan , Henry Guntur. 2009. Pengajaran Pragmatik. Bandung: Angkasa. 
Volume 71, Nomor 2, 1 Desember 2019 